\title{
Novel HPLC-UV Method for Simultaneous Determination of Fat-soluble Vitamins and Coenzyme Q10 in Medicines and Supplements
}

\author{
Žane Temova Rakuša, Eva Srečnik and Robert Roškar* \\ University of Ljubljana, Faculty of Pharmacy, Aškerčeva cesta 7, 1000 Ljubljana, Slovenia \\ * Corresponding author: E-mail: robert.roskar@ffa.uni-lj.si; \\ Tel: +38614769 655, Fax: +38614258031 \\ Received: $30-08-2016$
}

For Cutting Edge 2017

\begin{abstract}
A precise, accurate and rapid HPLC-UV method for simultaneous determination of fat-soluble vitamins (vitamin D3, E-acetate, K1, $\beta$-carotene, A-palmitate) and coenzyme Q10 was developed and validated according to ICH guidelines. Optimal chromatographic separation of the analytes in minimal analysis time ( $8 \mathrm{~min})$ was achieved on a Luna C18 150 $\times 4.6 \mathrm{~mm}$ column using a mixture of acetonitrile, tetrahydrofuran and water $(50: 45: 5, v / v / v)$. The described reversed phase HPLC method is the first published for quantification of these five fat-soluble vitamins and coenzyme Q10 within a single chromatographic run. The method was further applied for quantification of the analytes in selected liquid and solid dosage forms, registered as nutritional supplements and prescription medicines, which confirmed its suitability for routine analysis.
\end{abstract}

Keywords: Fat-soluble vitamins, coenzyme Q10, HPLC, nutrition supplements, pharmaceuticals

\section{Introduction}

Fat-soluble vitamins (FSVs) are essential for a variety of biochemical and physiological functions in human body, such as epithelial cell differentiation and vision (vitamin A), calcium and phosphate homeostasis (vitamin D), antioxidative protection in cell membranes (vitamin E) and blood coagulation (vitamin K). ${ }^{1,2}$ As FSV, with the exception of vitamin D3, cannot be obtained by endogenous synthesis, food or vitamin preparations are their main sources. Due to the large number of commercially available vitamin preparations and their widespread use, the quality control of these preparations is extremely important, especially because of the risk of toxicity from excessive intake of vitamins A and D. ${ }^{3}$

HPLC methods, coupled with different detection techniques: $\mathrm{UV},{ }^{4-12} \mathrm{FLD},{ }^{6} \mathrm{ECD},{ }^{13}$ and $\mathrm{MS}^{5,14}$ offer the best approach to accurate content determination of the main FSVs in foods, pharmaceuticals and nutritional supplements. The published HPLC-UV methods for quality control of preparations containing FSVs are quite limited in terms of separation and simultaneous determination of FSVs, ${ }^{4,5,7,8,11}$ often have run time longer than $15 \min ^{4-6,9,12}$ and generally require complicated and time-consuming sample preparation..$^{11,12,15,16}$ Further on, to our knowledge none of the published HPLC methods offer simultaneous determination of FSVs and also $\beta$-carotene and coenzyme Q10, which are often found along in medicines and nutritional supplements.

We aimed to develop rapid, accurate, precise and selective HPLC-UV method for simultaneous quantification of FSVs (in their most commonly used forms: A-palmitate, D3, E-acetate, K1 and A provitamin - $\beta$-carotene) and coenzyme Q10, using simple and fast extraction procedures (without alkaline saponification or solid phase extraction). The optimised HPLC method was successfully validated according to the ICH guidelines. In addition, medicines and nutritional supplements in liquid and solid dosage forms were analysed to confirm the adequacy of the method.

\section{Experimental}

\section{1. Chemicals and Reagents}

All FSVs (vitamin A-palmitate, D3, E-acetate, K1 and $\beta$-carotene), butylated hydroxytoluene (BHT), anhy- 
drous ferric chloride, $n$-hexane, $85 \%$ orthophosphoric acid $\left(\mathrm{H}_{3} \mathrm{PO}_{4}\right)$ and HPLC grade: acetonitrile,methanol and tetrahydrofuran (THF) were purchased from Sigma-Aldrich (Steinheim, Germany). Coenzyme Q10 (CoQ10) was obtained from Kaneka Corporation (Osaka, Japan). Ultra-pure water was obtained through a Milli-Q water purification system A10 Advantage (Millipore Corporation, Bedford, MA, USA).

\section{2. Instrumentation and Chromatographic Conditions}

Chromatographic analysis was performed on an Agilent 1100/1200 series HPLC system (Agilent Technologies, Waldbronn, Germany) equipped with UV-VIS detector and ChemStation data acquisition system. Chromatographic separation was performed on a reversed-phase Luna C18 (2) $150 \times 4.6 \mathrm{~mm}, 5 \mu \mathrm{m}$ particle size column (Phenomenex, Torrance, USA) at $25{ }^{\circ} \mathrm{C}$ using acetonitrile-tetrahydrofuran-water $(50: 45: 5, v / v / v)$ as a mobile phase at flow-rate of $1 \mathrm{~mL} / \mathrm{min}$. Injection volume (Vinj) was $20 \mu \mathrm{L}$ for all tested samples, except for samples from Preparation 2 and 3, where it was adjusted to 3 and 5 $\mu \mathrm{L}$, respectively. Detection was carried out at $270 \mathrm{~nm}$.

\section{3. Preparation of Standard Solutions}

Standard solutions of FSVs and CoQ10 were prepared fresh daily by dissolving appropriate amounts in $0.05 \%(\mathrm{~m} / \mathrm{v})$ solution of BHT in $n$-hexane. Nine calibration standards were prepared as mixtures of all tested compounds in $0.05 \%(\mathrm{~m} / \mathrm{v})$ solution of BHT in $n$-hexane in different concentration ranges for different analytes, selected considering the concentrations and proportions of the analytes in the investigated pharmaceutical formulations (Table 1). Quality control (QC) samples at three concentration levels were prepared by diluting separately prepared stock solutions with $0.05 \%(\mathrm{~m} / \mathrm{v})$ solution of BHT in $n$-hexane (Table 1). Prepared calibration standards and QC samples were evaporated to dryness under a stream of nitrogen at $40{ }^{\circ} \mathrm{C}$ (TurboVap LV, Caliper, Hopkinton-MA, USA). Dry residues were reconstituted in $1.0 \mathrm{~mL}$ of $0.01 \%(\mathrm{~m} / \mathrm{v})$ solution of BHT in mobile phase.

\section{4. Method Validation}

The method was validated according to ICH guidelines Q2(R1) ${ }^{17}$ in terms of selectivity, linearity, limit of quantification, precision, accuracy, recovery, sample stability and robustness.

Method selectivity was assessed by comparing chromatograms of individual standard solutions, mixture containing all standards, all used solvents and several common excipients found in commercial preparations (citric acid, sodium hydrogen phosphate, glycerol, propylene glycol, sodium benzoate, methyl- and propylparaben).

Linearity was evaluated based on nine calibration standards (Table 1). The procedure was repeated three times, using different stock solution, for three consecutive days of the validation. Injection volume during validation was $20 \mu \mathrm{L}$. Linearity was determined based on least-square linear regression. The acceptance criterion for determination coefficient was $\mathrm{R}^{2}>0.999$.

Limit of quantification (LOQ) was calculated from the regression lines, using the following equations: LOQ $=(10 \times \sigma) / \mathrm{S}$, where $\sigma$ is the standard deviation of the intercept, $\mathrm{S}$ is the average slope of the calibration curve.

Accuracy and precision were examined in terms of repeatability, precision and accuracy (intra- and interday) during three consecutive validation days, based on three $\mathrm{QC}$ samples covering low $\left(\mathrm{QC}_{\mathrm{L}}\right)$, medium $\left(\mathrm{QC}_{\mathrm{M}}\right)$ and high ranges $\left(\mathrm{QC}_{\mathrm{H}}\right)$ of the calibration standards (Table 1). QC samples were prepared separately, in triplicate, each day of the validation. Injection repeatability was evaluated on three concentration levels by re-injecting the same QC sample six times. Intra- and inter-day pre-

Table 1. Concentrations of calibration standards and QC samples

\begin{tabular}{|c|c|c|c|c|c|c|c|}
\hline & & & Co & on [ms & & & \\
\hline & & $\beta$-carotene & A-palmitate & D3 & CoQ10 & E-acetate & K1 \\
\hline Calibration & & 60 & 600 & 50 & 400 & 2600 & 150 \\
\hline standards & & 36 & 360 & 30 & 240 & 1560 & 90 \\
\hline & & 12 & 120 & 10 & 80 & 520 & 30 \\
\hline & & 6.0 & 60 & 5.0 & 40 & 260 & 15 \\
\hline & & 1.2 & 12 & 1.0 & 8.0 & 52 & 3.0 \\
\hline & & 0.60 & 6.0 & 0.50 & 4.0 & 26 & 1.5 \\
\hline & & 0.30 & 3.0 & 0.25 & 2.0 & 13 & 0.75 \\
\hline & & 0.12 & 1.2 & 0.10 & 0.80 & 5.2 & 0.30 \\
\hline & & 0.06 & 0.60 & 0.05 & 0.40 & 2.6 & 0.15 \\
\hline QC samples* & $\mathbf{Q C}_{\mathbf{H}}$ & 48 & 480 & 40 & 320 & 2080 & 120 \\
\hline & $\mathbf{Q C}_{\mathrm{M}}$ & 24 & 240 & 20 & 160 & 1040 & 60 \\
\hline & $\mathbf{Q C}_{\mathrm{L}}^{\mathrm{MI}}$ & 3.0 & 30 & 2.5 & 20 & 130 & 7.5 \\
\hline
\end{tabular}

* $\mathrm{QC}_{\mathrm{H}}, \mathrm{QC}_{\mathrm{M}}$ and $\mathrm{QC}_{\mathrm{L}}-$ quality control samples with high, medium and low concentrations 
cision (relative standard deviation - RSD) was expected to be not more that $5 \%$ ( $2 \%$ for injection repeatability) and intra- and inter-day accuracy (ratio (\%) between calculated concentration for the obtained QC response based on the line equation and nominal concentration, which was calculated considering the sample preparation) within $\pm 5 \%$. Accuracy of the injection volume variations was evaluated by re-injecting different volumes $(3,5,15,25$ and $30 \mu \mathrm{L})$ of the same QC sample three times and comparing it proportionally to the nominal value (injection volume $20 \mu \mathrm{L}$ ) and was expected to be within $\pm 5 \%$.

Sample stability was evaluated at three concentration levels (QC) and additionally in samples from Preparation 6 (tablets) and Preparation 7 (capsules) at $25^{\circ} \mathrm{C}$ for two days (at 0 and $24 \mathrm{~h}$ ) and was expressed as ratio between the concentration at $24 \mathrm{~h}$ and the concentration at time 0 . The acceptance criterion was $100 \pm 5 \%$.

Method recovery was determined by spiking preparation solutions with approximately the same amount of the analytes, as contained in the preparations, in triplicate. Non-spiked preparations and standard solutions containing the added amounts were separately analysed. Average recoveries were calculated by the formula: recovery $(\%)=100 \times($ concentration found in spiked sample - concentration found in unspiked sample) / added concentration.

The robustness of the method was investigated by deliberate modifications made to chromatographic conditions and sample preparation procedure. In sample preparation procedure for preparations in solid dosage form, different vortexing times (10 $\pm 5 \mathrm{~min})$, shaking times ( 30 $\pm 10 \mathrm{~min})$, sonication times $(10 \pm 5 \mathrm{~min})$ and different drying temperature $\left(40 \pm 5^{\circ} \mathrm{C}\right)$ were tested. To evaluate robustness in terms of chromatographic conditions, different injection volumes $(20 \pm 5 \mu \mathrm{L})$, column temperatures $(25 \pm$ $\left.2{ }^{\circ} \mathrm{C}\right)$, flow rates $(1.00 \pm 0.05 \mathrm{~mL} / \mathrm{min})$, detection wavelengths $(270 \pm 5 \mathrm{~nm})$ and mobile phase compositions acetonitrile-tetrahydrofuran-water (50.50:44.55:4.95 and 50:45:5 $v / v / v$ ) were tested.

\section{5. Sample Preparation of Nutritional Supplements and Medicines}

The validated method was further applied to assay vitamins and CoQ10 content in commercially available pharmaceutical preparations: three solutions, three tablets and two soft-shelled capsules, registered as medicines or nutritional supplements. Each preparation was prepared and analysed in triplicate.

Liquid preparations were either directly analysed (Preparation 2 and 3) or diluted 100-fold with $0.01 \%$ $(\mathrm{m} / \mathrm{v})$ solution of BHT in mobile phase prior to analysis (Preparation 1). The extraction procedure for tablets was as follows: one tablet (whole or powdered depending on the preparation) was added to $2.0 \mathrm{~mL}$ of $0.1 \% \mathrm{H}_{3} \mathrm{PO}_{4}$ into a centrifuge tube and vortexed for $10 \mathrm{~min}$. Organic solvent $(8.0 \mathrm{~mL}$ of $0.05 \%(\mathrm{~m} / \mathrm{v})$ solution of BHT in $n$-hexane) was added to the samples, before their further sonication (10 $\mathrm{min}$ ) and vortexing (2 min). Samples were then centrifuged for $10 \mathrm{~min}$ at $25^{\circ} \mathrm{C}$ and $5000 \mathrm{rpm}$. Fraction of the clear supernatant (1-3 $\mathrm{mL}$ depending on the preparation) was evaporated to dryness under a stream of nitrogen at $40{ }^{\circ} \mathrm{C}$ and reconstituted in $1.0 \mathrm{~mL}$ of $0.01 \%(\mathrm{~m} / \mathrm{v})$ solution of BHT in mobile phase. The content of vitamins and CoQ10 in soft-shelled capsules was evaluated by cutting one capsule in half and adding organic solvent ( $n$-hexane with $0.05 \%(\mathrm{~m} / \mathrm{v})$ BHT $:$ THF $=95: 5(\mathrm{v} / \mathrm{v}))$. The samples were sonicated $(10 \mathrm{~min})$, shaken $(30 \mathrm{~min})$ and centrifuged (10 $\left.\min , 25{ }^{\circ} \mathrm{C}, 5000 \mathrm{rpm}\right)$. The clear supernatant $(0.5 \mathrm{~mL})$ was evaporated to dryness under a stream of nitrogen at $40{ }^{\circ} \mathrm{C}$ and reconstituted in $1.0 \mathrm{~mL}$ of $0.01 \%(\mathrm{~m} / \mathrm{v})$ solution of BHT in mobile phase. Samples from preparations containing CoQ10 (Preparation 6 and 7) were additionally reconstituted in $1.0 \mathrm{~mL}$ of $0.1 \%(\mathrm{~m} / \mathrm{v})$ solution of $\mathrm{Fe}^{3+}$ in mobile phase, which acts as an oxidant and enables evaluation of total CoQ10.

\section{Results and Discussion}

\section{1. Optimization of Chromatographic Conditions}

The main objective of the study was to obtain optimal analytical method in terms of sample preparation and chromatographic conditions for simultaneous quantification of FSVs and CoQ10 in medicines and nutritional supplements. Chromatographic conditions were optimized in order to achieve baseline separated, symmetric peaks of the target analytes in minimal analysis time. Selection of stationary phase (various $\mathrm{C} 18$ reversed phase analytical columns) was based on our experience and previous research. Several mixtures of acetonitrile and methanol in isocratic and gradient modes were tested and found suitable for chromatographic separation of all tested analytes except CoQ10, which eluted only after THF was added to the mobile phase. Various mixtures of acetonitrile, THF and water at flow rates $0.5-2.0 \mathrm{~mL} / \mathrm{min}$ and column temperatures $25-40{ }^{\circ} \mathrm{C}$ and detection wavelengths $210-325$ $\mathrm{nm}$ were tested to optimize the chromatographic separation of all tested vitamins as well as both reduced and oxidized form of CoQ10. Detection wavelength $270 \mathrm{~nm}$ was selected as optimal compromise between absorbance of the individual analytes and their concentration in the tested preparations, with particular reference to vitamins D3 and $\mathrm{K} 1$, which have the lowest contents in the tested multivitamin preparations. Optimized chromatographic conditions resulted in symmetric and separated peaks with a short run time (Figure 1). The obtained run time is considerably shorter in comparison to other similar published HPLC-UV methods. ${ }^{4-6,9,12}$ 


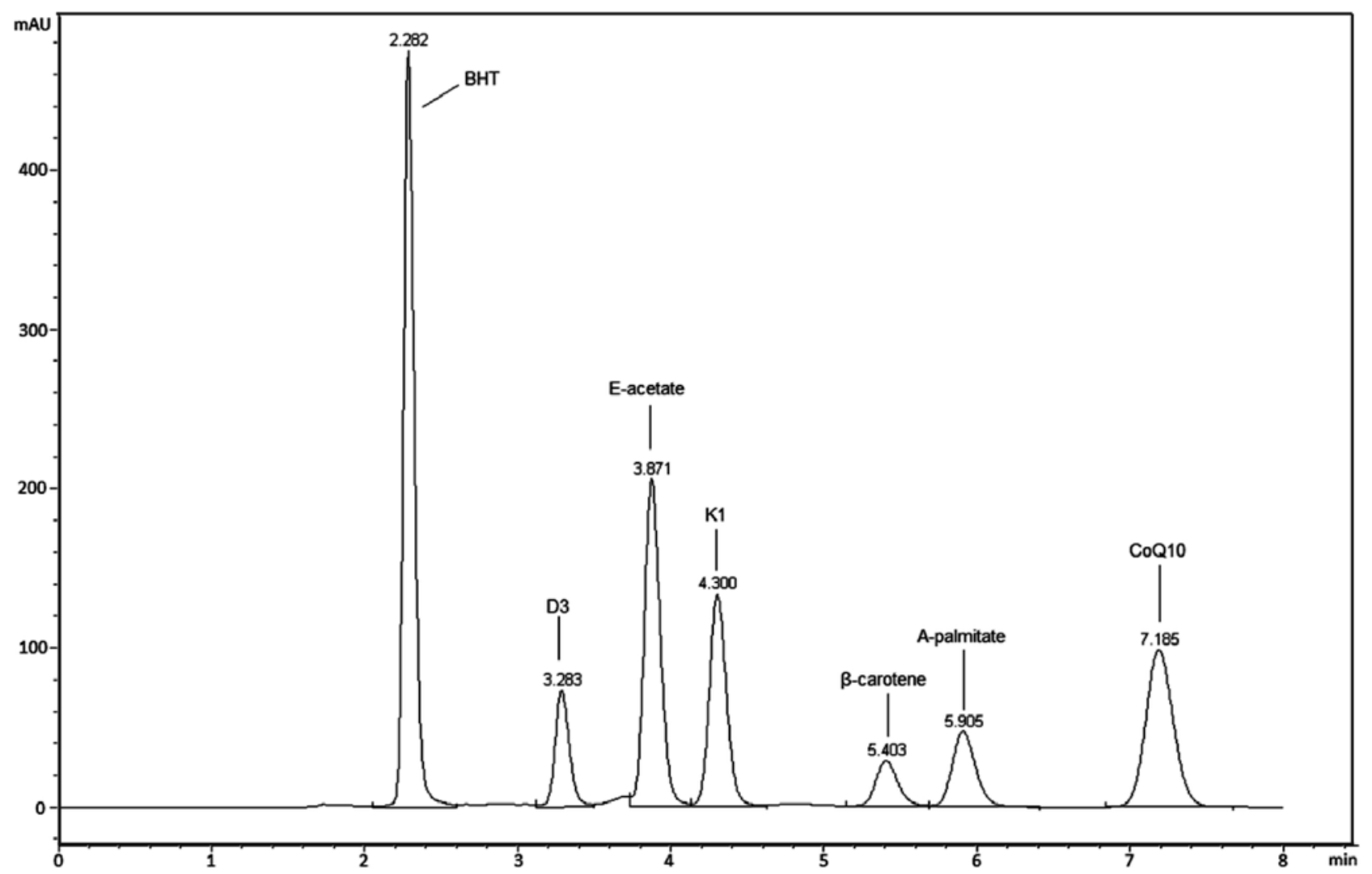

Figure 1: A chromatogram of standard mixture of fat-soluble vitamins and coenzyme Q10.

\section{2. Optimization of Sample Preparation}

The optimised HPLC method was further applied to evaluate the content of FSVs and CoQ10 in commercial pharmaceuticals with particular attention to sample preparation, as a crucial step in the analysis of medicines and nutritional supplements. We aimed to develop simple and fast extraction procedure with a minimal number of steps and solvent consumption.

The extraction procedure for tablets was adjusted from Temova and Roškar's method for vitamin D3 extraction, ${ }^{18}$ which comprised of addition of $0.1 \% \mathrm{H}_{3} \mathrm{PO}_{4}$ to two tablets, vortexing for $2 \mathrm{~min}$, subsequent addition of methanol $(8.0 \mathrm{~mL})$, sonication $(10 \mathrm{~min})$, vortexing $(2 \mathrm{~min})$ and centrifugation of the samples. In order to determine the optimal method, studies were done with $(2.0 \mathrm{~mL})$ and without the addition of $0.1 \% \mathrm{H}_{3} \mathrm{PO}_{4}$ to one powdered tablet. Hereafter, different shaking times $(0,2,4,5$ and 15 min with vortex mixer and 30 min with rotary mixer), organic solvents (methanol, $n$-hexane and mobile phase), sonication times $(0,5,10,15 \mathrm{~min})$, further shaking times $(0,2$ and 4 min with vortex mixer and 30 min with rotary mixer) and centrifugation times $(0,10$ and $15 \mathrm{~min})$ at 25 ${ }^{\circ} \mathrm{C}$ and $5000 \mathrm{rpm}$ were tested. The best extraction in terms of method recoveries was achieved with the addition of $2.0 \mathrm{~mL}$ of $0.1 \% \mathrm{H}_{3} \mathrm{PO}_{4}$ into a centrifuge tube with one tab- let, vortexing for $10 \mathrm{~min}$ and addition of $0.05 \%(\mathrm{~m} / \mathrm{v})$ solution of BHT in $n$-hexane $(8.0 \mathrm{~mL})$, before their further sonication (10 $\mathrm{min})$ and vortexing $(2 \mathrm{~min})$. Samples were then centrifuged for $10 \mathrm{~min}$ at $25^{\circ} \mathrm{C}$ and $5000 \mathrm{rpm}$.

The optimization of the extraction procedure for soft-shelled capsules started with investigation of extraction organic solvents (anhydrous ethanol, methanol, $n$-hexane, different mixtures of $n$-hexane and methanol, mobile phase, $n$-hexane:THF $=95: 5(v / v))$, to determine the optimal solvent, which was found to be $n$-hexane with $0.05 \%(\mathrm{~m} / \mathrm{v})$ BHT $:$ THF $=95: 5(\mathrm{v} / \mathrm{v})$. THF was added to solve the issue of poor solubility of $\beta$-carotene. Further on, sonication time $(0,5,10,15 \mathrm{~min})$, shaking time (15, $30,45,60 \mathrm{~min}$ ) and reconstitution solvent (methanol, mobile phase and $0.01 \%(\mathrm{~m} / \mathrm{v})$ solution of BHT in mobile phase) were tested in order to obtain optimal recoveries of the extraction procedure. The final extraction parameters (10 min sonication, $30 \mathrm{~min}$ shaking and $0.01 \%(\mathrm{~m} / \mathrm{v})$ solution of BHT in mobile phase as reconstitution solvent) provided suitable recoveries and sample stability of all analytes (Table 3).

\section{3. Method Validation}

Selectivity of the method was confirmed as no interfering peaks were found at retention times of the selected 
analytes (Figure 1). The standard calibration curves were linear over concentration ranges as presented in Table 2. Appropriate linearity was achieved with the addition of lipophilic antioxidant - BHT, especially for vitamin A-palmitate $\left(R^{2}=0.9945\right.$ without $\left.B H T\right)$ and $\beta$-carotene $\left(R^{2}=\right.$ 0.9935 without BHT). As shown in Table 2 on the example of QC medium sample, intra-day, inter-day and accuracy of the injection volume variations was better than \pm $5 \%$ at all times, which is within the defined acceptance criteria. Similarly, intra and inter-day precision were below $3 \%$ in all cases and injection repeatability was less than $2 \%$ (Table 2). Sample stability after $24 \mathrm{~h}$ was asses- sed in order to ensure that the obtained concentration results adequately reflect those directly after sampling. Stability of all tested analytes in QC samples and samples from Preparation 6 and 7 after $24 \mathrm{~h}$ in the autosampler at $25{ }^{\circ} \mathrm{C}$ was within the defined acceptance criteria $100 \pm$ $5 \%$. Such sample stability in QC samples was obtained after the addition of BHT, especially for vitamin A-palmitate and $\beta$-carotene, which were found subject to extensive degradation without appropriate stabilization with BHT (22 and 70\% after $24 \mathrm{~h}$ for vitamin A-palmitate and $\beta$-carotene, respectively). Method was found robust to slight changes in both chromatographic and sample preparation

Table 2. Validation data

\begin{tabular}{|c|c|c|c|c|c|c|c|c|c|}
\hline \multirow[b]{2}{*}{ Analyte } & \multirow[b]{2}{*}{$\begin{array}{l}\text { Range } \\
\text { [mg/L] }\end{array}$} & \multirow[b]{2}{*}{$\begin{array}{c}\text { LOQ } \\
{[\mathrm{mg} / \mathrm{L}]}\end{array}$} & \multirow[b]{2}{*}{$\mathbf{R}^{2}$} & \multicolumn{3}{|c|}{ Accuracy } & \multicolumn{3}{|c|}{ Precision } \\
\hline & & & & $\begin{array}{c}\text { Intra- } \\
\text { day }\end{array}$ & $\begin{array}{c}\text { Inter- } \\
\text { day }\end{array}$ & $\begin{array}{l}\text { Variation } \\
\text { of Vinj* }\end{array}$ & $\begin{array}{c}\text { Intra- } \\
\text { day }\end{array}$ & $\begin{array}{c}\text { Inter- } \\
\text { day }\end{array}$ & $\begin{array}{c}\text { Injection } \\
\text { repeatability }\end{array}$ \\
\hline A-palmitate & $1.2-600$ & 1.2 & 0.9996 & 100.90 & 100.96 & $99.7-101.4$ & 0.27 & 0.20 & 0.19 \\
\hline CoQ10 & $0.80-400$ & 0.80 & 0.9997 & 100.89 & 100.94 & $100.0-101.5$ & 0.53 & 0.98 & 0.10 \\
\hline D3 & $0.25-50$ & 0.15 & 0.9998 & 100.99 & 101.06 & 99.9-100.9 & 0.55 & 2.69 & 0.24 \\
\hline E-acetate & $2.6-2600$ & 1.5 & 0.9996 & 99.93 & 99.90 & $99.1-103.2$ & 0.56 & 2.32 & 0.14 \\
\hline $\mathrm{K} 1$ & $0.30-150$ & 0.20 & 0.9997 & 101.18 & 101.24 & $100.0-101.7$ & 0.40 & 0.87 & 0.13 \\
\hline$\beta$-carotene & $0.12-60$ & 0.12 & 0.9997 & 101.24 & 101.30 & $100.0-100.4$ & 0.52 & 1.28 & 1.83 \\
\hline
\end{tabular}

* different injection volumes $(3,5,15,25$ and $30 \mu \mathrm{L})$, calculated to nominal injection volume $20 \mu \mathrm{L}$
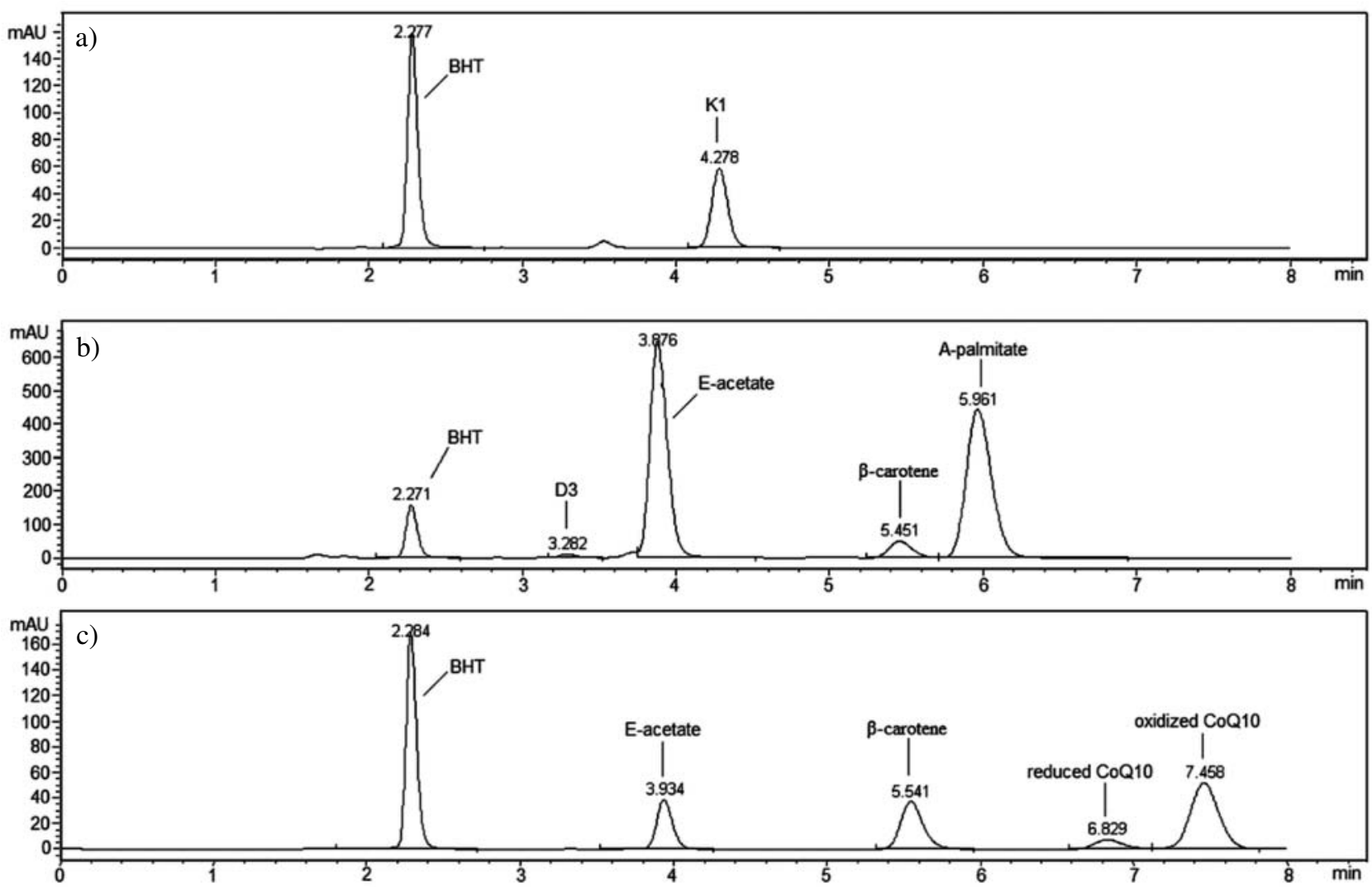

Figure 2: Representative chromatograms of a): Preparation 1 - solution, b): Preparation 5 - tablets and c): Preparation 7 - capsules, which also contains a reduced form of CoQ10 that is chromatographically separated from its general form (oxidized CoQ10). 
parameters. The obtained results from samples prepared with deviations in the sample preparation procedure, were accurate $(100 \pm 5 \%)$ and precise $(\mathrm{RSD}<5 \%)$. In all varied chromatographic conditions the resolution between the studied compounds was not altered, demonstrating the robustness of the method.

\section{4. Assay in Nutritional Supplements and Medicines}

In order to test the applicability of the developed and validated HPLC method to commercial multi-vitamin preparations, six pharmaceutical preparations, registered as medicines and two nutritional supplements in various dosage forms (solutions, tablets, soft shelled capsules) were tested to evaluate the content of the analytes in relation to the value claimed on the label. Liquid preparations were either directly analysed (Preparation 2 and 3) or diluted with $0.01 \%(\mathrm{~m} / \mathrm{v})$ solution of BHT in mobile phase prior to analysis (Preparation 1). Samples from tablets and capsules were prepared according to the optimised extraction procedure (Section 3.2) Representative chromatograms of samples from all three dosage forms are presented in Fi- gure 2. The results for average contents and calculated method recoveries are presented in Table 3 . High recoveries and low standard error values (Table 3 ) confirmed the suitability of the established HPLC method for quantification of the target analytes in liquid and solid preparation without any pre-treatment (Preparation 2 and 3 ) or after a simple and rapid pre-treatment (other preparations).

\section{Conclusions}

The main novelty in our approach is the developed HPLC method, which to our knowledge, is the first published method for simultaneous determination of five fatsoluble vitamins (A-palmitate, D3, E-acetate, K1 and A provitamin - $\beta$-carotene) and coenzyme Q10. Moreover, analysis time of only $8 \mathrm{~min}$ is favourable in comparison to other published HPLC-UV methods for determination of fewer fat-soluble vitamins. The obtained results from the assay in commercial nutrition supplements and medicines confirmed that the method is appropriate for routine analysis and quality control of multi-vitamin products in pharmaceutical and health food industries. Considering

Table 3. Average content in medicines and nutritional supplements along with method recoveries $(n=3)$

\begin{tabular}{|c|c|c|c|c|c|}
\hline & & Analyte & Declared content & $\begin{array}{c}\text { Determined content } \\
\text { (average } \pm \text { standard error }[\%])\end{array}$ & $\begin{array}{c}\text { Method recovery }^{\#} \\
{[\%]}\end{array}$ \\
\hline \multirow{7}{*}{$\begin{array}{l}\stackrel{n}{0} \\
\stackrel{0}{\Xi} \\
\stackrel{0}{0}\end{array}$} & \multirow{7}{*}{ Medicines } & & & 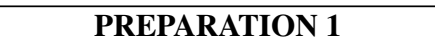 & \\
\hline & & $\mathrm{K} 1$ & $10 \mathrm{mg} / \mathrm{mL}$ & $9.97 \pm 0.02 \mathrm{mg} / \mathrm{mL}$ & 103.8 \\
\hline & & & & PREPARATION 2 & \\
\hline & & A-palmitate & $3300 \mu \mathrm{g} / \mathrm{mL}$ & $4594 \pm 3 \mu \mathrm{g} / \mathrm{mL}$ & \\
\hline & & D3 & $50 \mu \mathrm{g} / \mathrm{mL}$ & $62.4 \pm 0.2 \mu \mathrm{g} / \mathrm{mL}$ & 100.1 \\
\hline & & & & PREPARATION 3 & \\
\hline & & D3 & $100 \mu \mathrm{g} / \mathrm{mL}$ & $114.7 \pm 0.3 \mu \mathrm{g} / \mathrm{mL}$ & 98.4 \\
\hline \multirow{14}{*}{$\frac{\frac{0}{0}}{\frac{0}{\pi}}$} & \multirow{9}{*}{ Medicines } & & & PREPARATION 4 & \\
\hline & & A-palmitate & $330 \mu \mathrm{g} / \mathrm{tbl}$ & $394 \pm 1 \mu \mathrm{g} / \mathrm{tbl}$ & 99.3 \\
\hline & & D3 & $2 \mu \mathrm{g} / \mathrm{tbl}$ & $2.43 \pm 0.04 \mu \mathrm{g} / \mathrm{tbl}$ & 99.3 \\
\hline & & & & PREPARATION 5 & \\
\hline & & A-palmitate & $2750 \mu \mathrm{g} / \mathrm{tbl}$ & $3336 \pm 55 \mu \mathrm{g} / \mathrm{tbl}$ & 94.2 \\
\hline & & D3 & $10 \mu \mathrm{g} / \mathrm{tbl}$ & $12.2 \pm 0.1 \mu \mathrm{g} / \mathrm{tbl}$ & 95.8 \\
\hline & & E-acetate & $15 \mathrm{mg} / \mathrm{tbl}$ & $17.8 \pm 0.3 \mathrm{mg} / \mathrm{tbl}$ & 96.9 \\
\hline & & $\beta$-carotene* & I & $0.120 \pm 0.003 \mathrm{mg} / \mathrm{tbl}$ & 104.2 \\
\hline & & & & PREPARATION 6 & \\
\hline & \multirow{5}{*}{$\begin{array}{l}\text { Nutritional } \\
\text { supplement }\end{array}$} & A-palmitate & $800 \mu \mathrm{g} / \mathrm{tbl}$ & $863 \pm 16 \mu \mathrm{g} / \mathrm{tbl}$ & 99.6 \\
\hline & & CoQ10 & $4.5 \mathrm{mg} / \mathrm{tbl}$ & $3.92 \pm 0.17 \mathrm{mg} / \mathrm{tbl}$ & 99.2 \\
\hline & & D3 & $5 \mu \mathrm{g} / \mathrm{tbl}$ & $7.32 \pm 0.07 \mu \mathrm{g} / \mathrm{tbl}$ & 104.8 \\
\hline & & E-acetate & $12 \mathrm{mg} / \mathrm{tbl}$ & $12.2 \pm 0.8 \mathrm{mg} / \mathrm{tbl}$ & 97.2 \\
\hline & & K1 & $25 \mu \mathrm{g} / \mathrm{tbl}$ & $18.1 \pm 0.7 \mu \mathrm{g} / \mathrm{tbl}$ & 97.4 \\
\hline \multirow{7}{*}{ 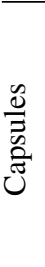 } & \multirow{5}{*}{ Medicine } & & & PREPARATION 7 & \\
\hline & & CoQ10 & $30 \mathrm{mg} / \mathrm{caps}$ & $28.6 \pm 0.1 \mathrm{mg} / \mathrm{caps}$ & 102.3 \\
\hline & & E-acetate & $24 \mathrm{mg} / \mathrm{caps}$ & $34.3 \pm 0.2 \mathrm{mg} / \mathrm{caps}$ & 98.1 \\
\hline & & $\beta$-carotene* & I & $3.36 \pm 0.02 \mathrm{mg} / \mathrm{caps}$ & 108.0 \\
\hline & & & & PREPARATION 8 & \\
\hline & \multirow{2}{*}{$\begin{array}{l}\text { Nutritional } \\
\text { supplement }\end{array}$} & E-acetate & $30 \mathrm{mg} / \mathrm{caps}$ & $45.5 \pm 0.8 \mathrm{mg} / \mathrm{caps}$ & 99.8 \\
\hline & & $\beta$-carotene & $7 \mathrm{mg} / \mathrm{caps}$ & $8.03 \pm 0.10 \mathrm{mg} / \mathrm{caps}$ & 108.2 \\
\hline
\end{tabular}

\footnotetext{
* content not defined; \# method recovery calculated according to the formula in section 2.4.
} 
that most of the tested preparations had considerably higher contents than labelled (up to $150 \%$ ), quality control of these preparations is of extreme importance.

\section{References}

1. S. Kucukkolbasi, N. Ires, H. Kara. J. Selcuk Univ. Nat. Appl. Sci. 2001, 30-47.

2. O. Heudi, M. Trisconi, C. Blake. J. Chromatogr. A 2004, 1022, 115-123. https://doi.org/10.1016/j.chroma.2003.09.062

3. F. Granado-Lorencio, E. Rubio, I. Blanco-Navarro, B. PérezSacristán, R. Rodríguez-Pena, F. J. García López. Food Chem. Toxicol. 2012, 50, 2106-8. https://doi.org/10.1016/j.fct.2012.03.001

4. S. N. Anuradha, S. Arunkumar. Int. J. Pharma. Bio. Sci. 2012, 3, 322-327.

5. D. E. Breithaupt, S. Kraut. Eur. Food Res. Technol. 2006, 643-649. https://doi.org/10.1007/s00217-005-0195-7

6. S. Kucukkolbasi, O. Bilber, H. Filiz Ayyildiz, H. Kara. Quim. Nov. 2013, 36, 1044-1051.

7. G. K入ackow, E. L. Anuszewska. Acta Pol. Pharm. 2000, 57 , 167-170.

8. B. Buszewski, W. Zbanyszek. J. Liq. Chromatogr. Relat. Technol. 2002, 25, 1229-1241.
https://doi.org/10.1081/JLC-120004021

9. L. Chen, L. Zhiyong, K. Xuejun, Z. Xiaoling, Z. Shenglan, G. Zhongze. Procedia Environ. Sci. 2011, 8, 588-595. https://doi.org/10.1016/j.proenv.2011.10.091

10. S. Wielinski, A. Olszanowski. J. Liq. Chrom. Rel. Technol. 2001, 24, 201-213. https://doi.org/10.1081/JLC-100001482

11. P. Moreno, V. Salvadó. J. Chromatogr. A 2000, 870, 207215. https://doi.org/10.1016/S0021-9673(99)01021-3

12. V. Kienen, W. F. Costa, J. V. Visentainer, N. E. Souza, C. C. Oliveira. Talanta 2008, 75, 141-146. https://doi.org/10.1016/j.talanta.2007.10.043

13. I. Acworth, P. Gamache. Thermo Fisher Scientific, Chelmsford, MA, USA.

14. C. Nimalaratne, C. Sun, J. Wu, J. M. Curtis, A. Schieber. Food Res. Int. 2014, 66, 69-77. https://doi.org/10.1016/j.foodres.2014.08.034

15. J. L. Luque-García, L. Castro. J. Chromatogr. A 2001, 935, 3-11. https://doi.org/10.1016/S0021-9673(01)01118-9

16. A. Jedlička, J. Klimeš. Chem. Pap. 2005, 59, 202-222.

17. International Conference on Harmonization (ICH) Guidelines, Q2(R1) Validation of analytical procedures, Commission of the European Communities, 2005.

18. Ž. Temova, R. Roškar. J. Chromatogr. Sci. 2016, 54, 1180-6. https://doi.org/10.1093/chromsci/bmw048

\section{Povzetek}

Razvili in validirali smo natančno, točno in hitro HPLC-UV metodo za sočasno vrednotenje lipofilnih vitaminov (vitamin D3, E-acetat, K1, $\beta$-karoten, A-palmitat) in koencima Q10. Optimalno kromatografsko ločbo analitov v kratkem času analize (8 min) smo dosegli na koloni Luna C18 $150 \times 4,6 \mathrm{~mm}$ z uporabo mobilne faze: acetonitril, tetrahidrofuran in voda (50: 45: 5, v/v/v). Opisana reverznofazna HPLC-UV metoda je prva objavljena analizna metoda za sočasno vrednotenje izbranih lipofilnih vitaminov in koencima Q10. Metodo smo nadalje uporabili za vrednotenje teh analitov v izbranih zdravilih in prehranskih dopolnilih, $\mathrm{v}$ tekočih in trdnih farmacevtskih oblikah ter tako potrdili njeno primernost za rutinsko uporabo. 